\title{
PENGGUNAAN GADGET SEBAGAI SUMBER BELAJAR MEMPENGARUHI HASIL BELAJAR PADA MATA KULIAH MATEMATIKA DASAR
}

\author{
Hastri Rosiyanti $^{1 *}$, Rahmita Nurul Muthmainnah ${ }^{2)}$ \\ Prodi Pendidikan Matematika, Universitas Muhammadiyah Jakarta \\ "hastrirosiyanti@gmail.com
}

\begin{abstract}
Abstrak
Latar belakang masalah ini didasari dari data rendahnya hasil belajar Matematika mahasiswa matematika dasar pada tahun 2017. Terdapat 2 dari 34 mahasiswa Matematika Dasar yang tidak lulus dengan nilai $D$ atau E, dan terdapat 7 mahasiswa yang memiliki nilai C. Faktanya dalam proses pembelajaran matematika dasar, mahasiswa efektif menggunakan gadget sebagai sumber belajar. Hal ini membuat penulis meneliti lebih lanjut untuk menguji adanya pengaruh dalam penggunaan sumber belajar melalui gadget terhadap hasil belajar Matematika mahasiswa matematika dasar tahun 2017. Jenis penelitian yang digunakan adalah penelitian sebab akibat dengan pendekatan kuantitatif. Sampel yang digunakan dalam penelitian ini adalah mahasiswa matematika dasar kelas A angkatan 2017 sebanyak 34 mahasiswa. Teknik pengumpulan data menggunakan hasil nilai mahasiwa dan angket. Teknik analisis data dilakukan dengan analisis regresi sederhana dari data hasil belajar mahasiswa matematika pada mata kuliah matematika dasar dan hasil angket siswa. Hasil dari penelitian ini, terdapat pengaruh dan signifikan penggunaan gadget terhadap hasil belajar matematika dasar. Hal ini menunjukkan bahwa variabel hasil belajar matematika mahasiswa matematika dasar, 26,9\% ditentukan oleh variabel penggunaan gadget sebagai sumber belajar dan sisanya ditentukan oleh variabel lain.
\end{abstract}

Kata Kunci: Gadget, Sumber Belajar, Hasil Belajar Matematika, Matematika Dasar

\section{PENDAHULUAN}

\section{Latar Belakang Masalah}

Matematika dasar merupakan mata kuliah awal bagi mahasiswa matematika pada Prodi Pendidikan Matematika FIP UMJ. Mata kuliah ini merupakan konsep dasar matematika sehingga diharapkan mahasiswa dapat berpikir secara deduksi dan sistematis. Oleh karea itu, dosen dapat memberikan arahan kepada mahasiswa dengan baik agar mahasiswa dapat mendapatkan hasil belajar yang optimal. Faktanya mahasiswa matematika angkatan 2017 pada mata kuliah matematika dasar memiliki hasil belajar yang rendah, yaitu terdapat 2 mahasiswa matematika dasar yang tidak lulus dengan nilai $\mathrm{D}$ atau $\mathrm{E}$, dan 
terdapat 7 mahasiswa yang memiliki nilai C, serta terdapat 2 mahasiswa yang memiliki nilai A. Hal ini terlihat bahwa hasil belajar matematika dasar pada mahasiswa matematika angkatan 2017 rendah.

Agar belajar dapat memperoleh hasil yang optimal, maka lingkungan belajar pun harus ikut mendukung. Berdasarkan Vygotsky (Marta, 2016) yang menyatakan bahwa lingkungan belajar hendaknya diciptakan sesuai dengan kebutuhan mahasiswa dalam belajar. Menciptakan lingkungan belajar yang baik dapat membantu mahasiswa dalam mencapai tujuan pembelajaran yang diinginkan. Dalam memperoleh pengetahuan, keterampilan dan sikap pada dasarnya dapat dicapai secara fleksibel, sebab sumber belajar terdapat dimana saja dengan berbagai beragam jenis dan bentuk. Kualitas interaksi mahasiswa dengan sumber belajar berpengaruh terhadap hasil belajar. Sehingga terdapat perbedaan hasil belajar antara mahasiswa yang memiliki intensitas tinggi dalam pemanfaatan sumber belajar dengan mahasiswa yang memiliki intensitas rendah dalam pemanfaatan sumber belajar.

Pada proses pembelajaran matematika dasar, mahasiswa memanfaatkan gadget sebagai sumber belajar. Gadget dalam pengertian secara umum dianggap sebagai suatu perangkat elektronik kecil yang memiliki fungsi khusus pada setiap perangkatnya. Gadget memiliki perbedaan dengan perangkat elektronik lainnya, yaitu adanya unsur kebaruan pada gadget, dimana dari waktu ke waktu gadget selalu menyajikan teknologi terbaru yang membuat hidup semakin praktis. Keunikan gadget adalah selalu memunculkan teknologi baru yang dinilai memudahkan penggunanya, sehingga pengguna merasa senang dan tertarik untuk memiliki dan menggunakan gadget. Contohnya mahasiswa lebih tertarik bermain gadget dan berbicara dengan teman sebelah tanpa memperhatikan penjelasan dosen. Gadget yang digunakan oleh mahasiswa berupa laptop, handphone, dan sebagainya.

Penggunaan gadget perlu diperhatikan, karena jika berlebihan dapat mengakibatkan dampak negatif bagi penggunanya, salah satunya yaitu pada segi interaksi sosial. Berdasarkan hasil penelitian terdahulu, dapat disimpulkan bahwa penggunaan gadget dalam sehari sekitar 2 sampai 3 jam lebih. Aktivitas yang paling sering dilakukan dengan gadget adalah berkomunikasi, seperti berkirim pesan singkat, panggilan telepon, berikirim e-mail, mengakses internet, jejaring sosial, bermain game, dan download. Berdasarkan aktivitas dalam menggunakan gadget, maka selain berdampak negatif dalam menggunakan gadget, adapaun dampak positif. Salah satu dampak positif, jika manusia menggunakan gadget maka manusia menjadi lebih pintar berinovasi akibat perkembangan gadget yang menuntut mereka untuk hidup lebih baik. Dalam penelitian ini, peneliti melihat mahasiswa memanfaatkan sumber belajar melalui gadget dilihat dari dampak positif, dimana mahasiwa menjadi lebih praktis dan paham dalam memperoleh ilmu yang diinginkan.

Berdasarkan uraian latar belakang masalah, penggunaan sumber belajar melalui gadget penting dalam mempengaruhi hasil belajar Matematika pada mahasiswa, maka peneliti merumuskan rumusan masalah penelitian, "apakah terdapat pengaruh penggunaan sumber belajar melalui gadget terhadap hasil belajar Matematika mahasiswa matematika dasar?" Sehingga tujuan dalam 
FIBONACCI : Jurnal Pendidikan Matematika dan Matematika. Vol. 4 (1), pp: 25-36.

penelitian ini untuk menguji bahwa terdapat pengaruh penggunaan sumber belajar melalui gadget terhadap hasil belajar Matematika mahasiswa matematika dasar.

\section{Hasil Belajar Matematika}

\section{Menurut Cornelius (Abdurrahman:} 2003) lima alasan perlunya belajar matematika karena matematika merupakan (1) sarana berpikir yang jelas dan logis, (2) sarana untuk memecahkan masalah kehidupan sehari-hari, (3) sarana mengenal pola-pola hubungan dan generalisasi pengalaman, (4) sarana untuk mengembangkan kreativitas, dan (5) sarana untuk meningkatkan kesadaran terhadap perkembangan budaya.

Belajar merupakan hal yang tidak dapat dipisahkan dari kehidupan setiap orang, karena belajar sangat berguna untuk perkembangan individu baik fisik maupun mental. Menurut Bloom belajar merupakan komponen ilmu pendidikan yang berkenaan dengan tujuan dan bahan acuan interaksi, baik yang bersifat eksplisit maupun implisit. Menurut Chaplin dalam Dictionary of Psychology membatasi belajar dengan dua macam rumusan. Rumusan pertama berbunyi belajar adalah perolehan perubahan tingkah laku yang relatif menetap sebagai akibat latihan dan pengalaman. Rumusan keduanya belajar ialah proses memperoleh respons-respons sebagai akibat adanya latihan khusus (Syah, 2007: 90). Bagi peserta didik, belajar pada dasarnya untuk memperoleh pengetahuan, keterampilan, dan sikap dimana saja, kapan saja, dan dengan apa saja, sebab sumber belajar terdapat dimana saja dan ada bermacam beragam jenisnya (Miarso, 2005).

Berdasarkan uraian sebelumnya, maka belajar dapat diartikan sebagai suatu proses yang dilakukan oleh individu dengan sumber belajar yang bertujuan untuk memperoleh perubahan yang dapat berupa pengetahuan keterampilan dan sikap. Belajar merupakan usaha yang dilakukan individu untuk memperoleh pengalaman atau pengetahuan baru yang dapat merubah tingkah laku, baik kognitif, afektif, maupun psikomotorik.

Pembelajaran merupakan proses yang dilakukan oleh pendidik dalam mengarahkan mahasiswa untuk mencapai tujuan yang diharapkan (Rosiyanti, 2015). Pembelajaran matematika merupakan proses aktivitas mahasiswa mengkonstruksi pengetahuan matematika. Belajar matematika berkaitan dengan segala proses penyelesaian masalah matematika. Mahasiswa memahami masalah matematika dengan benar akan menghasilkan hasil belajar matematika yang optimal.

Hasil belajar adalah hasil yang dicapai individu setelah mengalami proses adaptasi dengan lingkungannya maupun pengalamannya (belajar) (Rosiyanti, 2015). Matematika merupakan salah satu bidang yang ada pada semua jenjang pendidikan mulai dari tingkat sekolah dasar hingga perguruan tinggi. Matematika adalah suatu bidang studi tentang struktur-struktur abstrak yang membahas tentang pola-pola, seni, bangun ruang serta sebagai alat untuk mengekspresikan hubungan-hubungan kuantitatif dan keruangan untuk memudahkan berfikir (Huriyanti, 2017).

Hasil belajar matematika adalah hasil yang dicapai individu setelah mengalami proses adaptasi dengan lingkungannya maupun pengalamannya (belajar) dengan menggunakan bahasa simbol, sehingga mengajarkan individu untuk menggunakan nalarnya agar dapat berpikir logis (Rosiyanti, 2015). Peneliti menyimpulkan bahwa hasil belajar matematika adalah 
penilaian pendidikan tentang kemajuan mahasiswa dalam segala hal yang dipelajari yang menyangkut materi Matematika.

Menurut Benjamin S. Bloom tiga ranah (domain) hasil belajar, yaitu kognitif, afektif dan psikomotorik. Menurut A. J Romizowski hasil belajar merupakan keluaran (output) dari suatu sistem pemrosesan masukan (input). Masukan dari sistem tersebut berupa macam-macam informasi sedangkan keluarannya adalah perbuatan atau kinerja (performance) (Abdurrahman, 2012:26). Ranah kognitif terdiri dari 6 aspek yaitu pengetahuan, pemahaman, penerapan, analisis, sintesis dan penilaian. Pada penelitian ini, peneliti mengambil data hasil belajar Matematika berasal dari nilai akhir matematika dasar dengan 4 aspek, yaitu pengetahuan, pemahaman, penerapan dan analisis.

\section{Sumber Belajar}

Menurut Dageng, sumber belajar adalah segala sesuatu yang berwujud benda dan orang yang dapat menunjang belajar sehingga mencakup semua sumber yang mungkin dapat dimanfaatkan oleh tenaga pengajar agar terjadi perilaku belajar. Menurut Januszewski dan Molenda, sumber belajar adalah semua sumber termasuk pesan, orang, bahan, alat, teknik dan latar yang dapat dipergunakan peserta didik baik secara sendiri - sendiri maupun dalam bentuk gabungan untuk memfasilitasi kegiatan belajar dan meningkatkan kinerja belajar. Menurut Seels dan Richey, sumber belajar adalah segala sumber pendukung untuk kegiatan belajar, termasuk sistem pendukung dan materi serta lingkungan pembelajaran (Supriadi, 2015). Peneliti menyimpulkan bahwa sumber belajar adalah segala sumber pendukung untuk kegiatan belajar yang dipergunakan oleh peserta didik atau tenaga pengajar untuk memfasilitasi kegiatan belajar mengajar. Sumber belajar ini dapat berupa alat/barang atau orang.

Klasifikasi sumber belajar terdiri dari alat, orang dan lingkungan. Orang, bentuk sumber belajarnya adalah tenaga pengajar. Lingkungan, bentuk sumber belajarnya adalah perpustakaan, laboratorium, dan lainnya. Dalam penelitian ini, peneliti menggunakan klasifikasi sumber belajarnya adalah alat, yaitu gadget. Dimana alat yang merupakan alat yang sering disebut perangkat keras. Berkaitan dengan alat ini dipergunakan untuk mengeluarkan pesan yang tersimpan dalam bahan. Alat juga merupakan benda - benda yang berbentuk fisik yang sering disebut dengan perangkat keras, yang berfungsi untuk menyajikan bahan pembelajaran. Sumber belajar tersebut, seperti computer, OHP, kamera, radio, televise, film bingkai, tape recorder, dan VCD/DVD.

Dalam hubungannya dengan fungsi sumber belajar, Morrison dan Kemp mengatakan bahwa sumber belajar yang ada agar dapat difungsikan dan dimanfaatkan dengan sebaik - baiknya dalam pembelajaran. Fungsi sumber belajar bagi mahasiswa yaitu (a) mahasiswa lebih bersemangat dalam mengikuti perkuliahan atau proses pembelajaran, (b) memberikan kesempatan kepada mahasiswa untuk belajar sesuai dengan kemampuannya, sehingga memungkinkan untuk menemukan bakat terpendam pada mahasiswa yang selama ini tidak nampak, (c) mahasiswa dapat meningkatkan kemampuannya dalam menggunakan berbagai media komunikasi, (d) memberikan pengetahuan yang berlangsung terus menerus dan belajar menjadi mudah diserap dan lebih siap diterapkan, (e) mahasiswa dapat belajar 
FIBONACCI : Jurnal Pendidikan Matematika dan Matematika. Vol. 4 (1), pp: 25-36.

sesuai dengan kecepatan dan waktunya yang tersedia.

\section{Penggunaan Gadget}

Manusia sebagai makhluk hidup membutuhkan alat berkomunikasi untuk mendapatkan informasi, karena hal tersebut sudah menjadi kebutuhan yang penting untuk berinteraksi dan komunikasi dengan baik. Berdasarkan itu, manusia menciptakan sistem dan alat untuk dapat memudahkan manusia dalam berkomunikasi, mendapatkan informasi dan hiburan, mulai dari gambar, tulisan, suara, video, permainan, fasilitas internet, jejaring sosial yang dapat dilingkup dalam fitur fitur yang disajikan oleh gadget.

Gadget adalah sebuah istilah yang berasal dari bahasa inggris, yang artinya perangkat elektronik kecil yang memiliki fungsi khusus. Gadget sebagai perangkat alat elektronik kecil yang memiliki banyak fungsi. Gadget merupakan salah satu perkembangan teknologi komunikasi paling aktual di Indonesia selama beberapa tahun terakhir. Perbedaan gadget dengan perangkat elektronik lainnya yaitu unsur pembaharuan. Gadget adalah alat elektronik yang memiliki pembaharuan dari hari ke hari sehingga membuat hidup manusia lebih praktis. Sebagai contoh telepon rumah merupakan kategori perangkat elektronik. Bandingkan telepon rumah dengan handphone, dimana handphone lebih portable (mudah dibawa - bawa).

Dalam perkembangannya, gadget mengalamai perluasan arti. Sekarang gadget tidak hanya diartikan sebagai bentuk fisik (elektronik), tetapi sudah berkembang artinya dalam bentuk visual (software). Tetapi arti gadget masih sama, yaitu sebuah fitur untuk mempermudahkan kegiatan manusia. Secara garis besar, pengertian gadget adalah perangkat alat teknologi yang memiliki fungsi tertentu dan selalu mengalami perkembangan.

Fitur - fitur umum pada gadget adalah internet, kamera, video call, telepon, e-mail, SMS, Bluetooth, WIFI, game dan Mp3. Banyaknya jenis - jenis gadget yang berevolusi secara cepat menjadikan barang ini menarik untuk dimiliki. Adapun jenis jenis gadget seperti handphone, smartphone, laptop, tablet, iPad dalam berbagai merk seperti Samsung, Apple, SONY, OPPO, dan lainnya. Gadget dengan beragam jenis dalam merk memiliki fasilitas -fasilitas yang semakin hari semakin berkembang seiring perkembangan teknologi yang akhirnya menjadi salah satu kebutuhan manusia.

Gadget disamping memiliki fungsi utama sebagai alat komunikasi, juga dapat digunakan sebagai sarana bisnis, sumber informasi, penyimpanan berbagai macam data, sarana musik atau hiburan, jejaring sosial bahkan sebagai alat dokumentasi. Beberapa pemanfaatan gadget selain untuk komunikasi dan bermain, gadget dapat dimanfaatkan sebagai sarana belajar.

Tingkat penggunaan gadget pada manusia diduga dipengaruhi oleh beberapa karakteristik yaitu karakteristik yang berkaitan dengan diri sendiri maupun lingkungannya. Tujuan dalam menggunakan gadget dapat mempengaruhi tingkat interaksi sosial pada lingkungannya khususnya di lingkungan internal (keluarga) dan eksternal karena dengan tujuan berbeda dapat menyebabkan perbedaan dalam menggunakan gadget yang mereka miliki dengan semua fitur yang di fasilitas gadget. Sebagai contoh, mahasiswa menggunakan gadget bertujuan sebagai sarana belajar selain untuk berkomunikasi atau bermain. 
Penggunaan gadget memang harus memiliki batasan - batasan dan kriteria tertentu dalam pemakaian gadget untuk menghindari tingkat kecanduan manusia dalam menggunakan gadget. Penggunaan gadget dalam sehari sekitar 2 sampai 3 jam lebih.

Telah dipaparkan bahwa gadget memiliki banyak manfaat, lebih lanjut digunakan dengan cara yang benar dan semestinya. Penggunaan gadget terdapat dampak positif dan dampak negatif. Berikut dampak positif dalam menggunakan gadget, diantaranya:

1) Komunikasi menjadi lebih praktis. Adanya gadget, manusia dapat berkomunikasi dengan kerabatnya yang jaraknya jauh.

2) Imajinasi berkembang. Manusia yang bergaul dengan dunia gadget cenderung lebih kreatif. Manusia menjadi lebih pintar berinovasi akibat perkembangan gadget yang menuntut untuk hidup lebih baik.

3) Mudah mencari informasi. Mudahnya melakukan akses ke luar negeri.

4) Menambah kecerdasan. Manusia bisa belajar melalui gadget, dengan adanya rasa ingin tahu akan suatu hal.

5) Meningkatkan rasa percaya diri. Saat memenangkan suatu permainan akan termotivasi untuk menyelesaikan permainan yang lain.

6) Lebih berani. Terlatih mengoperasikan alat - alat teknologi lainnya.

Selain dampak positif, penggunaan gadget dapat juga berdampak negatif, yang dapat dilihat sebagai berikut.

1) Menjadi pribadi yang tertutup. Kecanduan yang diakibatkan oleh gadget dapat menggangu kedekatan orang lain sehingga menjadi pribadi yang tertutup.
2) Kesehatan terganggu. Akibat dari terlalu lama menatap layar gadget, mata dapat mengalami kelelahan hingga menyebabkan mata minus.

3) Gangguan tidur. Bermain gadget sampai larut malam sehingga paginya susah bangun.

4) Suka menyendiri. Intensitas bermain dengan kerabat secara perlahan akan semakin berkurang, sehingga lebih suka menyendiri bermain dengan gadget daripada bermain dengan kerabatnya.

5) Penyakit mental. Penggunaan gadget yang berlebihan menjadi depresi, kecemasan, kurangnya perhatian, autism, dan gangguan bipolar.

6) Agresif. Tanyangan - tanyangan yang terpapar di gadget menyebabkan menjadi lebih agresif, seperti tanyangan berisi pembunuhan, pemerkosaan, penganiayaan, dan kekerasan lainnya.

7) Adikasi. Merasa seakan tidak bias hidup tanpa gadget.

\section{Sumber Belajar Melalui Gadget}

Saat ini telah diciptakan beberapa gadget edukasi yang bertujuan untuk mempermudah dan mempercepat proses pembelajaran. Penggunaan gadget di kelas, seperti laptop, OHP, pointer laser, whiteboard interaktif, SmartBoards, perangkat elektronik digital lainnya mendorong dan memotivasi dosen untuk membuat pelajaran interaktif.

Gadget berkaitan dengan media pembelajaran berbasis ICT, oleh sebab itu biasanyan terhubung dengan internet. Dosen dapat memanfaatkan gadget sebagai sumber belajar bagi mahasiswa, seperti penggunaan laptop dan internet untuk mencari bahan belajar tambahan, dan mempermudah menyelesaikan tugas. Selain itu, penggunaan handphone yang berkamera 
dapat dimanfaatkan bagi mahasiswa untuk memotret slide atau tulisan yang dipaparkan oleh dosen, sehingga mahasiswa dapat mengikuti proses pembelajaran dengan mudah dan lancar. Handphone juga dapat bermanfaat sebagai alat perekam suara atau video, sehingga mahasiswa dapat merekam dosen saat mengajar guna sebagai arsip belajar mahasiswa. Kekurangan materi yang ada di buku dapat menjadi pendukung mahasiswa dalam memanfaatkan gadget sebagai sumber belajar. Pada abad 21 Gadget sudah menjadi sumber belajar bagi para pelajar terutama bagi mahasiswa, dengan adanya gadget pelajar tidak harus susah payah untuk ke perpustakaan mencari referensi cukup dengan jari semua yang di cari sudah mudah untuk di dapatkan. Hampir keseluruhan mengenai pelajaran semua sudah tersedia di dalam Gadget.

Adapun ada tiga klasifikasi penggunaan gadget dalam pembelajaran. a) Penggunaan gadget dapat sebagai tambahan dalam pembelajaran, yaitu jika mahasiswa mencari informasi tambahan lain selain informasi dari dosen. b) Penggunaan gadget sebagai penunjang dalam kegiatan pembelajaran, yaitu jika mahasiswa mempermudah mengerjakan tugas. c) Penggunaan gadget sebagai alternatif pendukung pembelajaran, yaitu saat dosen tidak dapat masuk kelas, dosen memberikan modul atau bahan belajar yang diunduh dan mengumpulkan tugas lewat email.

Indikator sumber belajar melalui gadget dapat dilihat sebagai berikut.

1) Belajar sendiri secara cepat. Meningkatkan pengetahuan, belajar interaktif, mengembangkan kemampuan di bidang penelitian

2) Memperkaya diri. Meningkatkan komunikasi dengan mahasiswa lain, meningkatkan kepekaan akan

permasalahan yang ada di seluurh dunia

3) Sebagai Pusat pembelajaran dan pendidikan. Mendapatkan informasi tentang ilmu pengetahuan, teknologi dan informasi lainnya.

\section{METODE PENELITIAN}

Penelitian ini merupakan penelitian sebab akibat, dengan tujuan untuk mengetahui hubungan antar masing masing variabel bebas atau keseluruhan dan varibel terikat. Populasi yang akan diteliti dalam penelitian ini adalah mahasiswa matematika dasar 2017 yang berjumlah 34 mahasiswa. Semua populasi akan dijadikan sampel, yaitu sebanyak 34 mahasiswa. Tempat penelitian yang peneliti lakukan di Kampus FIP UMJ dan penelitian ini dilaksanakan pada bulan Februari - Mei 2018.

Penelitian ini terdapat dua varibel yaitu, variabel bebas (independent) dan varibel terikat (dependent). Variabel bebas merupakan variabel yang mempengaruhi atau yang menjadi sebab perubahannya atau timbulnya variabel terikat. Variabel bebas dalam penelitian ini yaitu sumber belajar melalui gadget. Variabel penggunaan sumber belajar melalui gadget merupakan alat elektronik yang memiliki pembaharuan dari hari ke hari sehingga membuat hidup manusia lebih praktis. Indikator yang digunakan dalam penelitian ini berdasarkan: 1. belajar sendiri secara cepat, 2. memperkaya diri, 3. sebagai Pusat pembelajaran dan pendidikan.

Variabel terikat merupakan variabel yang dipengaruhi atau yang menjadi akibat karena adanya variabel bebas. Variabel terikat dalam penelitian ini yaitu hasil belajar Matematika. hasil belajar matematika adalah penilaian pendidikan 
tentang kemajuan mahasiswa dalam segala hal yang dipelajari yang menyangkut materi Matematika. Pada penelitian ini, peneliti mengambil data hasil belajar Matematika berasal dari nilai akhir matematika dasar dengan 4 aspek, yaitu pengetahuan, pemahaman, penerapan dan analisis.

Metode pengumpulan data adalah cara yang digunakan untuk mendapatkan data. Metode pengumpulan data yang digunakan dalam penelitian ini adalah tes hasil belajar Matematika dan angket. Metode pengumpulan data tes hasil belajar matematika diambil dari data nilai akhir pada mata kuliah matematika dasar.

Metode pengumpulan data angket ini dilakukan dengan cara memberikan daftar pernyataan pada responden yang berhubungan dengan penelitian dengan berbentuk pilihan. Adapun pilihan jawaban yang digunakan adalah sebagai berikut:

Tabel 1. Skor Setiap Pernyataan Angket

\begin{tabular}{cccc}
\hline $\begin{array}{c}\text { Pernyataan } \\
\text { Positif }\end{array}$ & \multicolumn{2}{c}{$\begin{array}{c}\text { Pernyataan } \\
\text { Negatif }\end{array}$} \\
\hline Sangat Setuju & 4 & $\begin{array}{c}\text { Sangat Setuju } \\
\text { (SS) }\end{array}$ & 1 \\
\hline Setuju & 3 & Setuju (SS) & 2 \\
\hline $\begin{array}{c}\text { Tidak Setuju } \\
\text { (TS) }\end{array}$ & 2 & $\begin{array}{c}\text { Tidak Setuju } \\
\text { (TS) }\end{array}$ & 3 \\
\hline $\begin{array}{c}\text { Sangat Tidak } \\
\text { Setuju (STS) }\end{array}$ & 1 & $\begin{array}{c}\text { Sangat Tidak } \\
\text { Setuju (STS) }\end{array}$ & 4 \\
\hline Angket & diisikan $\quad$ mahasiswa
\end{tabular}

berdasarkan pengalaman yang dialami. Dalam penelitian ini angket yang digunakan adalah angket penggunaan sumber belajar melalui gadget, sehingga pernyataanpernyataan yang disusun berdasarkan aspek-aspek penggunaan sumber belajar melalui gadget.

Dalam penelitian ini untuk menguji validitas butir item dalam angket menggunakan rumus korelasi product moment dari Pearson. Setelah diuji validitas, selanjutnya uji reliabilitas. Reliabilitas menunjukkan suatu instrumen cukup dapat dipercaya untuk digunakan sebagai alat pengumpul data karena instrumen tersebut sudah baik. Suatu angket dikatakan reliabel jika jawaban seseorang terhadap pernyataan adalah konsisten atau stabil dari waktu ke waktu. Mengukur reliabilitas dengan uji statistika Cronbach Alpha $(\alpha)$.

Analisis data merupakan suatu cara yang dilakukan dalam penelitian untuk membuktikan hipotesis yang diajukan selanjutnya untuk mengambil kesimpulan dari hasil yang diperoleh melalui analisis data tersebut. Langkah pertama data dianalisis dengan uji prasyarat regresi yang terdiri dari uji normalitas dan uji linearitas. Setelah itu langkah kedua dianalisis dengan uji asumsi klasik yaitu uji heteroskedastisitas. Setelah dilakukan dua tahap tersebut, langkah selanjutnya dilakukan pengujian hipotesis.

\section{HASIL DAN PEMBAHASAN}

Penelitian ini menggunakan analisis regresi linier sederhana. Pada analisis regresi linier sederhana terdapat tiga asusmsi klasik atau prasyarat analisis yang sebaiknya dipenuhi, yaitu normalitas, linearitas, dan homoskedastisitas.

\section{Uji Normalitas}

Metode ini mensyaratkan asumsi bahwa residual (RES) berasal dari populasi yang berdistribusi normal. Cara mendeteksi kenormalan eror prediksi adalah dengan Kolmogorov-Smirnov (K-S). 
Hastri Rosiyanti dan Rahmita N.M : Penggunaan Gadget Sebagai Sumber Belajar Mempengaruhi Hasil Belajar Pada Mata Kuliah Matematika Dasar

FIBONACCI : Jurnal Pendidikan Matematika dan Matematika. Vol. 4 (1), pp: 25-36.

Tabel 2. One Sample Kolmogorov Sminorv Test

\begin{tabular}{|c|c|c|}
\hline \multicolumn{2}{|l|}{ Keterangan } & Unstandardized Residual \\
\hline $\mathbf{N}$ & & 34 \\
\hline Normal Parametera, a,b & Mean & 0E-7 \\
\hline & Std. Deviation & 6.40321818 \\
\hline & Absolute & .096 \\
\hline Most Extreme Differences & Positive & .062 \\
\hline & Negative & -.096 \\
\hline Kolmogorov-Smirnov Z & & .557 \\
\hline Asymp. Sig. (2-tailed) & & .916 \\
\hline
\end{tabular}

Pada tabel 2 nilai signifikannya Uji Linearitas

adalah 0,916. Dikarenakan nilai signifikansinya lebih besar dari 0,05 maka keputusannya adalah terima $\mathrm{H}_{0}$ artinya residual (RES) berasal dari populasi yang berdistribusi normal.

Jika hubungan antara variabel bebas dengan terikat tidak bersifat linear, maka model regresi linear tidak cocok untuk digunakan.

Tabel 3. ANOVA

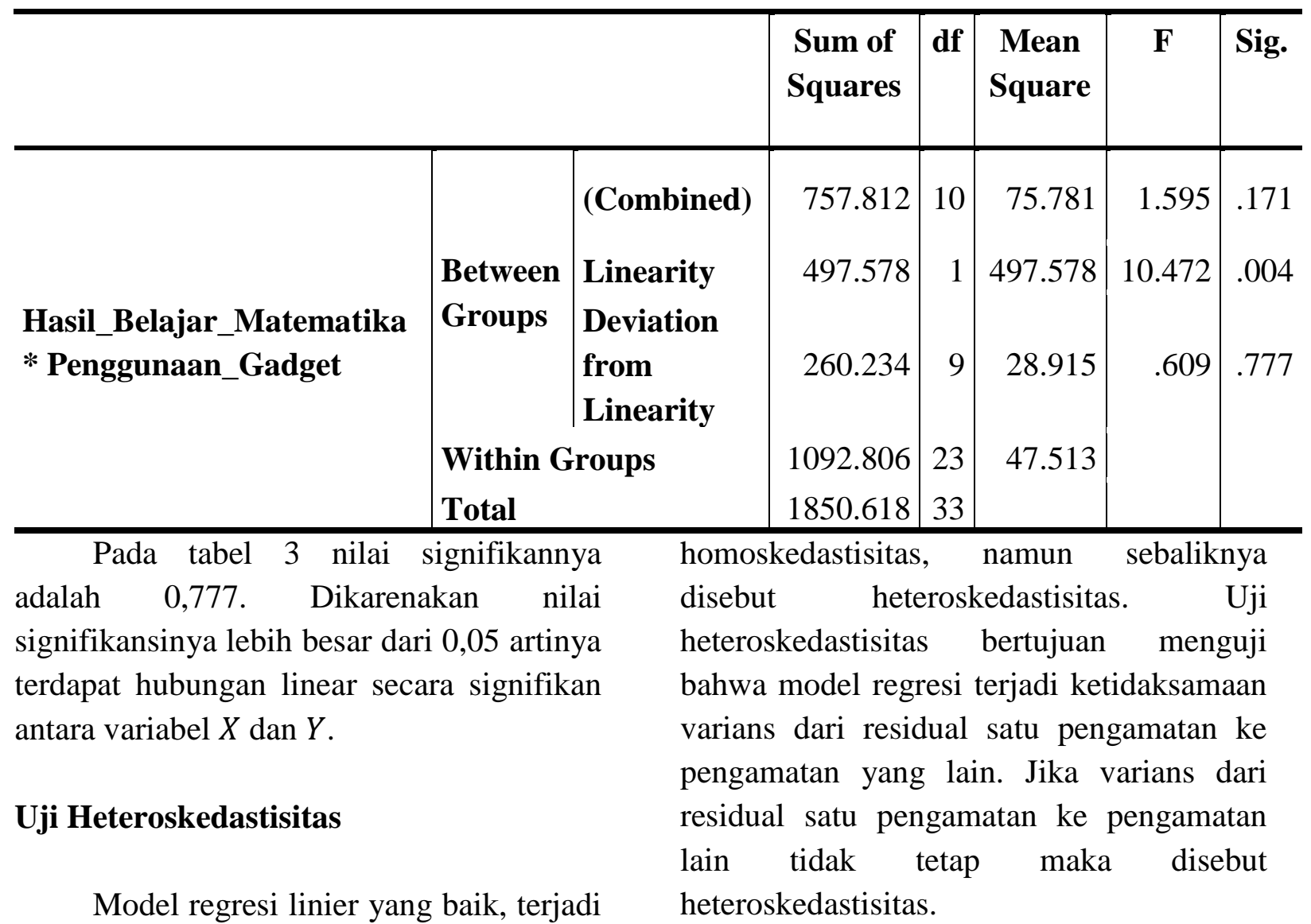
apabila eror prediksi bersifat konstan untuk setiap pengamatan dalam setiap variabel bebas. Asumsi ini bersifat 
Tabel 4. Coefficients I

\begin{tabular}{l|r|r|r|r|r}
\hline Model & \multicolumn{2}{|c|}{$\begin{array}{c}\text { Unstandardized } \\
\text { Coefficients }\end{array}$} & $\begin{array}{c}\text { Standardize } \\
\text { d } \\
\text { Coefficients }\end{array}$ & t Sig. \\
\cline { 2 - 5 } & \multicolumn{1}{|c|}{ B } & Std. Error & \multicolumn{1}{c|}{ Beta } & \\
\hline \\
\cline { 2 - 5 } $\begin{array}{l}\text { (Constant) } \\
\text { Penggunaan_Gadge } \\
\mathrm{t}\end{array}$ & 15.979 & 7.998 & & 1.998 & .054 \\
\hline
\end{tabular}

a. Dependent Variable: RES2

Pada tabel 4 nilai signifikannya adalah $0,170 . \quad$ Dikarenakan nilai signifikansinya lebih besar dari 0,05 artinya tidak terjadi heteroskedastisitas pada variabel $X$.

\section{Uji Hipotesis}

Pengujian hipotesis dalam penelitian ini dilakukan dengan menggunakan teknik

Tabel 5. Model Summary

\begin{tabular}{l|r|r|r|r|r}
\hline $\begin{array}{l}\text { Mode } \\
\mathbf{l}\end{array}$ & \multicolumn{1}{|c|}{$\mathbf{R}$} & \multicolumn{1}{c|}{$\begin{array}{c}\text { R } \\
\text { Square }\end{array}$} & $\begin{array}{c}\text { Adjusted R } \\
\text { Square }\end{array}$ & $\begin{array}{c}\text { Std. Error } \\
\text { of the } \\
\text { Estimate }\end{array}$ & $\begin{array}{l}\text { Durbin- } \\
\text { Watson }\end{array}$ \\
\hline 1 & $.519^{\mathrm{a}}$ & .269 & .246 & 6.50250 & 1.919 \\
\hline
\end{tabular}

a. Predictors: (Constant), Penggunaan_Gadget

b. Dependent Variable: Hasil_Belajar_Matematika

Pada tabel 5 nilai Durbin Watson $(d)=1,919 \quad$. Karena banyaknya variabelnya 2 maka nilai $K=2$ dan sampel yang diteliti adalah 34 maka $T=34$. Tabel 6. Coefficients II regresi sederhana. Sebelum menguji hipotesis akan dilakukan uji durbin Watson. Tujuan uji durbin Watson adalah untuk mendeteksi terjadinya autokorelasi pada nilai residual dari sebuah analisis regresi. Autokorelasi adalah hubungan antara nilainilai yang dipisahkan satu sama lain dengan jeda waktu tertentu.

\begin{tabular}{|c|c|c|c|c|c|c|}
\hline \multirow{2}{*}{\multicolumn{2}{|c|}{ Model }} & \multicolumn{2}{|c|}{$\begin{array}{c}\text { Unstandardized } \\
\text { Coefficients }\end{array}$} & \multirow{2}{*}{$\begin{array}{c}\text { Standardize } \\
\text { d } \\
\text { Coefficients }\end{array}$} & \multirow[t]{2}{*}{$\mathbf{t}$} & \multirow[t]{2}{*}{ Sig. } \\
\hline & & B & Std. Error & & & \\
\hline \multirow{2}{*}{1} & (Constant) & 27.440 & 12.670 & & 2.166 & .038 \\
\hline & Penggunaan_Gadget & .657 & .192 & .519 & 3.430 & .002 \\
\hline
\end{tabular}

a. Dependent Variable: Hasil_Belajar_Matematika

Berdasarkan tabel Durbin Watson, nilai $D L=1,39285$ dan $D U=1,51358$. Karena $d>D U$ maka tidak terdapat autokorelasi positif dan $(4-d)>D U$ maka tidak terdapat autokorelasi negatif. 
Hastri Rosiyanti dan Rahmita N.M : Penggunaan Gadget Sebagai Sumber Belajar Mempengaruhi Hasil Belajar Pada Mata Kuliah Matematika Dasar

FIBONACCI : Jurnal Pendidikan Matematika dan Matematika. Vol. 4 (1), pp: 25-36.

Berdasarkan tabel 6, maka persamaan

garis regresi dapat dinyatakan dalam persamaan sebagai berikut:

$$
Y=27,440+0,657 x
$$

Karena persamaan regresi linier adalajh $Y=a+b x$ maka nilai $a=27,440$ artiya jika tidak ada penggunaan gadget maka nilai konsisten nilai matematika dasar adalah 27,440. Begitu pula dengan $b=0,657$ artinya setiap penambahan $1 \%$ tingkat penggunaan gadget maka hasil belajar matematika akan meningkat 0,657 .

Berdasarkan tabel 5 menunjukkan nilai $R$ yang merupakan simbol dari harga koefisien korelasi sebesar 0,519. Dengan koefisien determinasi $\left(r^{2}\right)$ sebesar 0,269. Hal ini menunjukkan bahwa variabel hasil belajar matematika mahasiswa matematika dasar, 26,9\% ditentukan oleh variabel $X$ dan sisanya ditentukan oleh variabel lain.
Berdasarkan tabel 6 diketahui nilai signifikan sebesar 0,02 yang dimana kurang dari 0,05 akibatnya $\mathrm{H}_{0}$ ditolak artinya terdapat pengaruh penggunaan gadget terhadap hasil belajar matematika dasar.

\section{SIMPULAN}

Terdapat pengaruh dan signifikan penggunaan gadget terhadap hasil belajar matematika dasar. Hal ini ditunjukkan dengan nilai signifikan sebesar 0,02 dimana kurang dari 0,05. Hal ini menunjukkan bahwa variabel hasil belajar matematika mahasiswa matematika dasar, 26,9\% ditentukan oleh variabel $X$ dan sisanya ditentukan oleh variabel lain.

\section{UCAPAN TERIMA KASIH}

Peneliti mengucapkan terimakasih kepada ketua Lembaga Penelitian dan Pengabdian Masyarakat (LPPM) UMJ yang telah mengizinkan dan mendanai peneliti untuk melakukan penelitian ini.

\section{DAFTAR PUSTAKA}

Abdurrahman, Mulyono. 2012. Anak Berkesulitasn Belajar (Teori, Diagnotis dan Remediasinya). Jakarta: Rineka Cipta

Marta, Finola Putri. 2016. Pengembangan Bahan Ajar Matematika Dasar Layanan Jurusan Non Eksak. Jurnal Fibonacci: Pendidikan Matematika dan Matematika. Vol 2 (1), pp 44-52

Miarso. 2005. Menyemai Benih Teknologi Pendidikan. Jakarta: Kencana

Huriyanti, Luthfi., dan Hastri Rosiyanti. 2017. "Perbedaan Motivasi Belajar Matematika Siswa Setelah Menggunakan Strategi Pembelajaran Quick On The Draw”. Fibonacci: Jurnal Pendidikan Matematika dan Matematika. Vol. 3 (1), pp: 65-76. 
FIBONACCI : Jurnal Pendidikan Matematika dan Matematika

Volume 4 No.1 Bulan Juni Tahun 2018

Rosiyanti, Hastri. 2015. "Implementasi Pendekatan Pembelajaran Konstruktivisme Terhadap Pemahaman Konsep Matematika Mahasiswa Materi Transformasi Linier”. Jurnal Fibonacci: Pendidikan Matematika dan Matematika. Vol 1 (2), pp 25-36

Rosiyanti, Hastri., dan Esti Wijayanti. 2015. "Implementasi Model Pembelajaran Treffinger Terhadap Hasil Belajar Matematika dan Sikap Siswa”. Jurnal Fibonacci: Pendidikan Matematika dan Matematika. Vol 1 (2), pp 37-44

Supriadi, 2015. "Pemanfaatan Sumber Belajar Dalam Proses Pembelajaran". Lantanida Journal. Vol 3 (2)

Syah, Muhibbin. 2007. Psikologi Pendidikan dengan Pendekaan Baru. Bandung: PT Remaja Rosdakarya. 